Meta

Journal des traducteurs

Translators' Journal

\title{
Saudi Students' Translation Strategies in an Undergraduate Translator Training Program
}

\section{Omar Atari}

Volume 50, numéro 1, mars 2005

Enseignement de la traduction dans le monde

Teaching Translation Throughout the World

URI : https://id.erudit.org/iderudit/010667ar

DOI : https://doi.org/10.7202/010667ar

Aller au sommaire du numéro

Éditeur(s)

Les Presses de l'Université de Montréal

ISSN

0026-0452 (imprimé)

1492-1421 (numérique)

Découvrir la revue

Citer cet article

Atari, O. (2005). Saudi Students' Translation Strategies in an Undergraduate Translator Training Program. Meta, 50(1), 180-193.

https://doi.org/10.7202/010667ar
Résumé de l'article

L'objet de cette étude est de présenter les résultats d'une étude empirique sur les stratégies employées, lors de l'opération traduisante, par les étudiants saoudiens en traduction au niveau de la licence. La méthode appliquée est «l'introspection à haute voix». L'étude montre que les étudiants ont tendance à utiliser plus fréquemment les stratégies d'analyse sur le plan du mot et de la phrase dans leur compréhension du texte-source aussi bien que dans leur production du texte-cible (les stratégies linguistiques de base). Très rarement ils utilisent les autres stratégies, notamment l'inférence et le raisonnement et celles fondées sur le bagage cognitif et culturel du traducteur et sur le texte en tant qu'unité globale. Aussi, le chercheur recommande d'entraîner les apprenants aux stratégies peu utilisées et à l'analyse des éléments du texte à un niveau supérieur à celui du simple mot et de la phrase.
Ce document est protégé par la loi sur le droit d'auteur. L'utilisation des services d’Érudit (y compris la reproduction) est assujettie à sa politique d'utilisation que vous pouvez consulter en ligne.

https://apropos.erudit.org/fr/usagers/politique-dutilisation/ 


\title{
Saudi Students' Translation Strategies in an Undergraduate Translator Training Program
}

\author{
OMAR ATARI \\ King Saud University, Riyad, Saudi Arabia \\ atari_omar@yahoo.com
}

\begin{abstract}
RÉSUMÉ
L'objet de cette étude est de présenter les résultats d'une étude empirique sur les stratégies employées, lors de l'opération traduisante, par les étudiants saoudiens en traduction au niveau de la licence. La méthode appliquée est «l'introspection à haute voix». L'étude montre que les étudiants ont tendance à utiliser plus fréquemment les stratégies d'analyse sur le plan du mot et de la phrase dans leur compréhension du texte-source aussi bien que dans leur production du texte-cible (les stratégies linguistiques de base). Très rarement ils utilisent les autres stratégies, notamment l'inférence et le raisonnement et celles fondées sur le bagage cognitif et culturel du traducteur et sur le texte en tant qu'unité globale. Aussi, le chercheur recommande d'entraîner les apprenants aux stratégies peu utilisées et à l'analyse des éléments du texte à un niveau supérieur à celui du simple mot et de la phrase.
\end{abstract}

\begin{abstract}
This paper reports on the findings of an empirical study conducted on the strategies employed by a sample of undergraduate Saudi translator trainees while translating. The study uses the think-aloud protocol (i.e. the subjects' verbal reports of what's going on in their heads while translating) as a technique for soliciting the data. The researcher has found that the strategies of ST and TT monitoring at the word or sentence level are employed most frequently (i.e. language-based strategies). Other important strategies, namely text contextualization and inferencing and reasoning are the least frequently used (i.e. knowledge-based strategies). Hence, the need for training translator trainees in the use of these strategies as well as the recognition and utilization of larger textual elements.
\end{abstract}

\section{MOTS-CLÉS/KEYWORDS}

contextualization, inferencing, think-aloud protocol, translation strategies, Saudi students

\section{Overview}

The growing interest in translation within the Arab world has manifested itself in the emergence of translator training programs, both at graduate and undergraduate levels in several Arab universities (e.g. Saudi Arabia, Morocco, Jordan). This newlyemerging trend has, as a matter of course, resulted in an upsurge of research into translation studies. The major thrust of this research has been product-oriented. Therefore, it exhibits the features of contrasting the target text with the source text (Henceforth TT and ST).

One major strand of these product-oriented contrastive studies attempted, and rightly so, to base its analysis on the interaction between micro-text and macro-text processing. Emery (1991:129-137), for instance, acknowledges that both macrodimensions (discoursal, textual, pragmatic and semiotic) and micro-dimensions (syntactic, lexical) of the translation process are inextricably intertwined and inter- 
dependent. (Cf. Farghal, 1995; Menacere, 1992; Emery, 1989; Shunnaq, 1999; Aziz, 1985; Atari, 1994).

The second strand of these product-oriented research studies has taken up the issue of shifts in tenor and register in the target texts (Henceforth TT). For instance Farghal and Shunnaq (1995: 208) addressed the tenor-related problems in the translation of legal texts into Arabic. (Cf. Shaker 1995; Asfour, 2000; Farghal and Naji 2000; Ali, 1988; Sa'Adeddin, 2000, among others).

The Hatim and Mason model (1990) represents a third strand of analysis. It proceeds according to a clear vision of the linkage between product and process that seeks to capture the intricate dialectic underpinning of genre, discourse and text. Hence, they present a tripartite framework for the analysis of the communicative, pragmatic and semiotic dimensions of texts.

It should be noted here that this brief review of the relevant product-oriented studies with reference to English and Arabic is by no means exhaustive. It provides a preliminary account of the directions taken by researchers into translation studies that address the issues related to English and Arabic.

This review of published studies demonstrates the dirth of process-oriented research. To the best of my knowledge the only study that could be classified as a process-oriented piece of research is the one by Khanji et al. (2000:448-557) in which they classify the strategies used by Arabic-speaking translators' strategies in simultaneous interpretation.

As translation teachers and researchers, we must be interested in process-oriented research that takes account of the mental processes and transformations embedded within the act of translation. So far, there has been a severe shortage of this type of research. This paper seeks to provide a counter weight to this imbalance. It examines Arab translator trainees' strategies of translation through the use of the think-aloud technique.

This paper will describe the translation strategies employed by a sample of undergraduate Arabic-speaking translator trainees (i.e. Saudis) engaged in the act of translating from English into Arabic. Thus, the paper shall examine not only the strategies used frequently, but those strategies that are not used. In its conclusion, the paper will pursue the implications of our findings and offer recommendations for the teaching methods of translation.

\section{Method of Data Collection: The Dialogue Protocol}

As a reaction to the limitations of the product-oriented approach, the think-aloud protocols have been used to reveal aspects of the translation process. The use of think-aloud reveals both the strategies and the mental processes associated with them. (Cf. Krings 1986; Lörscher, 1986, 1991; Kussmall, 1995; Börsch, 1986).

Due to the danger of influencing the subjects' responses during the monologue think-aloud (i.e. the subject is trying to inform the instructor/researcher what is going on inside the head while sometimes being prompted by the researcher), I have employed a dialogue between pairs of translator trainees. This approach groups translator trainees into pairs, each member of pair was asked to translate from English into Arabic individually. During the act of translation the individuals were encouraged to interact with each other. Their enquiries, comments, etc. were tape-recorded. 


\section{Framework: Translation Strategies}

Lörscher (1996: 27-28) defines translation strategies as procedures that the subjects employ in order to solve translation problems. He adds:

“... accordingly, translation strategies have their starting-point in the realization of a problem by a subject, and their termination in a (possibly preliminary) solution to the problem or in the subject's realization of the insolubility of the problem at the given point in time. Between the realization of a translation problem and the realization of its solution or insolubility, further verbal and lor mental activities can occur which can be interpreted as being strategy steps or elements of translation strategies."

Lörscher's model consists of the following:

TABLE (1)

\begin{tabular}{|l|l|}
\hline Strategy & Definition \\
\hline RR & Realizing a translational problem \\
\hline VP & Verbalizing a translational problem \\
\hline SP & Search for a (possible preliminary) solution to a translational problem \\
\hline SP & Solution to a translational problem \\
\hline SP a, b, c... & Parts of a solution to a translational problem \\
\hline SP $\varnothing$ & A solution to a translational problem is still to be found $(\varnothing)$ \\
\hline SP $=\varnothing$ & Negative $(\varnothing)$ solution to a translational problem \\
\hline PSL & Problem in the reception of the SL text \\
\hline
\end{tabular}

In addition to these original elements of translation strategies, Lörscher (1996:28) proposes other potential elements which consist of:

\begin{tabular}{|l|l|}
\hline Strategy & Definition \\
\hline MSL/MTL & Monitoring (verbatim repetition) of SL- \& TL- text segments \\
\hline REPHR SL/TL & $\begin{array}{l}\text { Rephrasing (paraphrasing) of SL- \& TL- text segments and other potential } \\
\text { elements of checking solutions and mental organization of SL- TL- text } \\
\text { segments (for a detailed view of the model, see Lörscher (1996: 27-29). }\end{array}$ \\
\hline
\end{tabular}

Krings (1986:267) offers the following eleven features for a model of translation strategies:

\begin{tabular}{|l|l|}
\multicolumn{2}{l|}{ TABLE (2) } \\
\hline Strategy & Strategy and Sequence \\
\hline 1 & The subjects' explicit statement of problems \\
\hline 2 & The use of reference books (i.e. dictionaries) \\
\hline 3 & The underlining of source-language text passages \\
\hline 4 & The Semantic analysis of source-language text items \\
\hline 5 & Hesitation phenomena in the search for potential equivalents \\
\hline 6 & Competing potential equivalents \\
\hline 7 & The monitoring of potential equivalents \\
\hline 8 & Specific translation principles \\
\hline 9 & The modification of written target-language texts \\
\hline 10 & The assessment of the quality of the chosen translation \\
\hline 11 & Paralinguistic or non-linguistic features (i.e. groaning and sighing) \\
\hline
\end{tabular}


Gerloff (1986:253) offers the following model which comprises features similar to Krings' and Lörscher's. Her categories combine ST comprehension strategies and TT production strategies. These are:

TABLE (3)

\begin{tabular}{|c|c|}
\hline Strategy Type & Characterization \\
\hline $\begin{array}{l}\text { Problem } \\
\text { Identification }\end{array}$ & $\begin{array}{l}\text { A subject identifies a word as unknown or current difficulty as } \\
\text { being due to a mistranslated word from the previous paragraph. } \\
\text { This also includes linguistic analysis of syntactic and lexical } \\
\text { structures. }\end{array}$ \\
\hline Storage and Retrieval & $\begin{array}{l}\text { A subject searches memory for SL or TL equivalents, identifies } \\
\text { a word as remembered or never seen before, or waits for word } \\
\text { to "emerge into consciousness." This also includes dictionary use. }\end{array}$ \\
\hline $\begin{array}{l}\text { General Search } \\
\text { and Selection }\end{array}$ & $\begin{array}{l}\text { A subject repeats pronunciation of linguistic units in SL or TL, } \\
\text { gives synonyms, alternative meanings or tentative meanings, } \\
\text { uses fillers or skips them. He compares the two languages } \\
\text { as language systems. }\end{array}$ \\
\hline $\begin{array}{l}\text { Inferencing and } \\
\text { Reasoning Strategies }\end{array}$ & $\begin{array}{l}\text { A subject uses general world knowledge or personal experience } \\
\text { to question, hypothesize or declare a meaning. } \\
\text { He also refers to author intent to question, hypothesize or } \\
\text { state a meaning. } \\
\text { He explains the text, having constructed an interpretation } \\
\text { from use of other contexts. } \\
\text { He uses text structure. }\end{array}$ \\
\hline Text Contextualization & $\begin{array}{l}\text { A subject restates prior information obtained from the text. } \\
\text { He uses sentence, paragraph or larger contexts. }\end{array}$ \\
\hline Editing & $\begin{array}{l}\text { Immediate correction or alteration/selection of meaning } \\
\text { choices before writing. } \\
\text { Congruity assessment } \\
\text { A subject checks to see if the translation makes sense; } \\
\text { maybe before writing the product or after. } \\
\text { He checks punctuation marks. } \\
\text { Product quality assessment } \\
\text { A subject makes overt reference to the quality of his own } \\
\text { translation and makes changes, additions, deletions, etc. }\end{array}$ \\
\hline $\begin{array}{l}\text { Extratextual or } \\
\text { Language Use \& } \\
\text { Task Monitoring }\end{array}$ & $\begin{array}{l}\text { A subject makes discovery comments, offers personal opinion } \\
\text { on information in the text or comments on self as a learner, } \\
\text { laughs, sighs, groans, etc. or refers to experimenter directly. }\end{array}$ \\
\hline
\end{tabular}

In brief, the aforementioned models of translation strategies are quite comparable with each other. They all attend to ST reading comprehension strategies and production strategies despite the variance in their use of terminology. For purposes of my study, after, preliminary examination of my subjects' dialogue protocols, I chose to use Gerloff's model (1986:274-262) with a few refinements of her terminology. Specifically, I chose the label "Monitoring of ST segment" instead of her "General Search and Selection" strategy. In addition, I used the category "Monitoring of TT segments" instead of her "Editing." 


\section{Results / Observations}

\section{General Observations}

I would like to point out here that the subjects sometimes tend to employ a variety of strategy types while handling the same ST or TT segment. Specifically, within the context of solving one translation problem, subjects tend to employ more than one strategy - often with a cluster of strategies. When a translation problem is being identified, subjects employ strategies of ST processing for comprehension such as re-reading, repeating pronunciation of a problematic ST segment, giving alternatives or tentative meanings for it in either the ST or TT. Thus, they infer a tentative selection of meaning choices and do immediate self-corrections. Then and almost simultaneously, they check the proposed TT segment (i.e. product) by constructing explanatory context either on the basis of personal experience, world knowledge or sentence context. They tend to go back to a ST segment in the preceding sentence or phrase to ascertain the appropriateness of their proposed TT segment. Yet, they quite often leave the proposed TT segment unchecked in order to move forward to handle a new ST segment thinking it will provide more insights into what they have already proposed.

The course of the translation process is actually spiral, comprising a tripartite hierarchical structure using three strategies: ST comprehension strategy leading to a prospective TT segment that is checked and re-checked through the employment of a TT monitoring strategy based on inference and reasoning. Lörscher (1986:287) refers to this non-linear, discontinuous translation process course as:

"The translational process of problem solving which manifests itself largely as a retrospective-prospective process can thus be compared to a chain of spirals. Although it generally proceeds in a prospective way, what proceeds is not of a purely linear kind. Rather it can be seen as a chain of loops with both retrospective and prospective elements."

\section{Specific Observations}

In the following section of the paper I report on three elements: the number and type of strategies used, the most frequently used strategies and their substrategies and third, the least frequently used strategies and their substrategies. These results direct us as teachers of translation to the relevance of the strategy types that are neglected, in the hope that we start to pay special attention to them in our classroom translation teaching. The strategies most frequently used, on the other hand, will be looked at as another pointer to their relevance or irrelevance of ST reading comprehension and TT production (i.e. the two primary phases of a translation act). 
CHART (1)

Saudi Student's Use of Translation Strategies

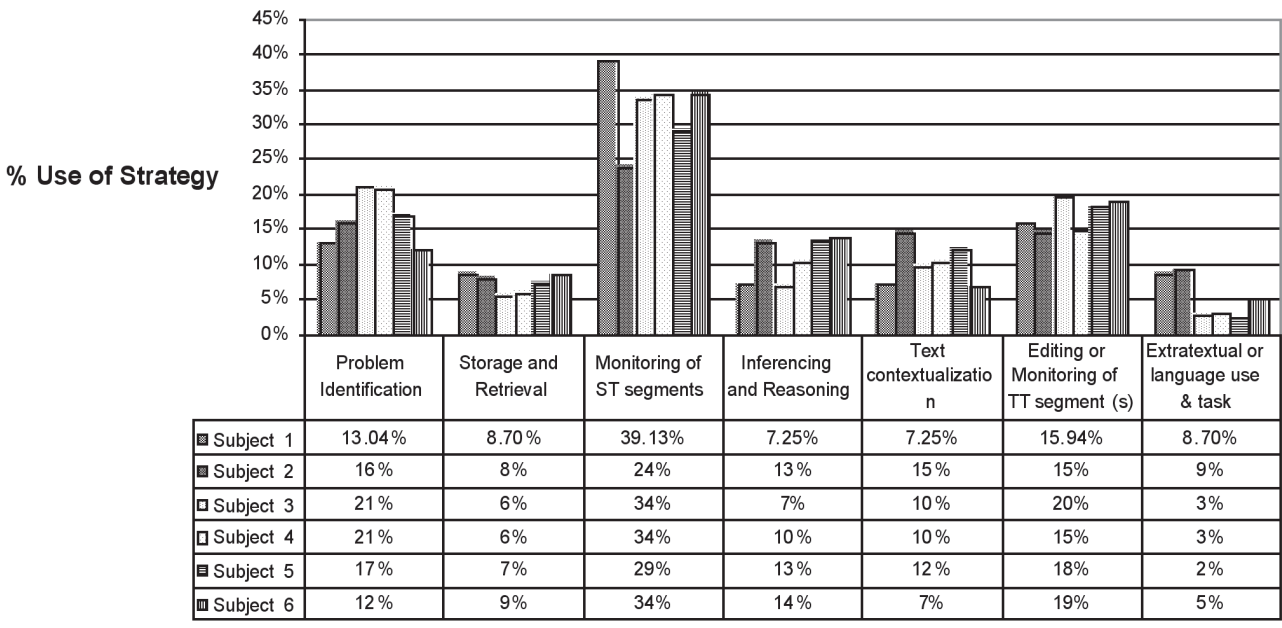

\section{Strategy}

TABLE (1)

Saudi Students' Use of Translation Strategies:

Frequence of Use of Strategy Type and Substrategies

\begin{tabular}{|c|c|c|c|c|c|c|c|}
\hline \multirow{2}{*}{\multicolumn{2}{|c|}{ Strategy Used and Its Substrategies }} & \multirow{2}{*}{\multicolumn{2}{|c|}{$\begin{array}{l}\text { Subject } 1 \\
\# \quad \%\end{array}$}} & \multirow{2}{*}{\multicolumn{2}{|c|}{$\begin{array}{l}\text { Subject } 2 \\
\# \quad \%\end{array}$}} & \multirow{2}{*}{\multicolumn{2}{|c|}{$\begin{array}{l}\text { Subject } 3 \\
\# \quad \%\end{array}$}} \\
\hline & & & & & & & \\
\hline I- & Problem Identification & 9 & $13.04 \%$ & 12 & $16.00 \%$ & 15 & $21.13 \%$ \\
\hline 1 & Question meaning of a word & 5 & & 2 & & 8 & \\
\hline 2 & Question meaning of a clause, phrase or sentence & 2 & & 4 & & 4 & \\
\hline 3 & Syntactic and lexical analysis & 2 & & 6 & & 3 & \\
\hline & Storage and Retrieval & 6 & $8.70 \%$ & 6 & $8.00 \%$ & 4 & $5.63 \%$ \\
\hline 1 & $\begin{array}{l}\text { Memory search } \\
\text { e.g. searches memory for English or Arabic } \\
\text { equivalent, Identifies a word or waits for a word } \\
\text { to emerge into "consciousness" }\end{array}$ & 0 & & 0 & & 0 & \\
\hline 2 & Dictionary use & 6 & & 6 & & 4 & \\
\hline III- & Monitoring of ST segments & 27 & $39.13 \%$ & 18 & $24.00 \%$ & 24 & $33.80 \%$ \\
\hline 1 & Repeats linguistic unit & 9 & & 3 & & 7 & \\
\hline 2 & Re-reads ST segment & 6 & & 2 & & 8 & \\
\hline 3 & Generates synonyms & 2 & & 1 & & 1 & \\
\hline 4 & Gives tentative meanings or alternatives & 9 & & 8 & & 8 & \\
\hline 5 & Filters words, skips them & 1 & & 4 & & 0 & \\
\hline 6 & Compares English \& Arabic & 0 & & 0 & & 0 & \\
\hline & Inferencing and Reasoning & 5 & $7.25 \%$ & 10 & $13.33 \%$ & 5 & $7.04 \%$ \\
\hline 1 & World knowledge & 1 & & 2 & & 0 & \\
\hline 2 & Personal experience & 1 & & 2 & & 0 & \\
\hline 3 & Refers to author intent & 2 & & 1 & & 1 & \\
\hline 4 & Constructs explanatory context & 1 & & 5 & & 3 & \\
\hline 5 & Text structure & 0 & & 0 & & 1 & \\
\hline
\end{tabular}




\begin{tabular}{|ll|c|c|c|c|c|c|}
\hline V- & 5 & $7.25 \%$ & 11 & $14.67 \%$ & 7 & $9.86 \%$ \\
\hline $1 \quad$ Restates prior information & 3 & & 5 & & 0 & \\
\hline 2 & Uses sentence context & 1 & & 3 & & 6 & \\
\hline $3 \quad$ Uses paragraph context & 1 & & 0 & & 0 & \\
\hline $4 \quad$ Uses larger context & 0 & & 3 & & 1 & \\
\hline VI- Editing or Monitoring of TT segments & 11 & $15.94 \%$ & 11 & $14.67 \%$ & 14 & $19.72 \%$ \\
\hline $1 \quad$ Immediate correction or alteration/selection & & & & & & \\
& of meaning choices & 6 & & 5 & & 5 & \\
\hline $2 \quad$ Congruity assessment & 3 & & 3 & & 5 & \\
\hline $3 \quad$ Punctuation check & 0 & & 0 & & 0 & \\
\hline $4 \quad$ Product quality assessment & 2 & & 3 & & 4 & \\
\hline VII- Extratextual or language use \& task monitoring & 6 & $8.70 \%$ & 7 & $9.33 \%$ & 2 & $2.82 \%$ \\
\hline $1 \quad$ Discovery comments & 1 & & 2 & & 0 & \\
\hline $2 \quad$ Laughs & 1 & & 1 & & 0 & \\
\hline $3 \quad$ Offers personal opinion & 2 & & 4 & & 2 & \\
\hline $4 \quad$ Comments on self as a learner & 2 & & 0 & & 0 & \\
\hline $5 \quad$ Refers to experimenter directly & 0 & & 0 & & 0 & \\
\hline Total & 69 & & 75 & & 71 & \\
\hline
\end{tabular}

Table (1) continued

\begin{tabular}{|c|c|c|c|c|c|c|c|}
\hline \multirow{2}{*}{\multicolumn{2}{|c|}{ Strategy Used and Its Substrategies }} & \multirow{2}{*}{\multicolumn{2}{|c|}{\begin{tabular}{cc}
\multicolumn{2}{c}{ Subject 4} \\
$\# \quad \%$
\end{tabular}}} & \multirow{2}{*}{\multicolumn{2}{|c|}{$\begin{array}{c}\text { Subject } 5 \\
\# \quad \%\end{array}$}} & \multirow{2}{*}{\multicolumn{2}{|c|}{$\begin{array}{l}\text { Subject } 6 \\
\# \quad \%\end{array}$}} \\
\hline & & & & & & & \\
\hline I- & Problem Identification & 14 & $20.90 \%$ & 14 & $17.07 \%$ & 7 & $12.07 \%$ \\
\hline 1 & Question meaning of a word & 8 & & 10 & & 5 & \\
\hline 2 & Question meaning of a clause, phrase or sentence & 3 & & 1 & & 2 & \\
\hline 3 & Syntactic and lexical analysis & 3 & & 3 & & 0 & \\
\hline II- & Storage and Retrieval & 4 & & 6 & $7.32 \%$ & 5 & $8.62 \%$ \\
\hline 1 & $\begin{array}{l}\text { Memory search } \\
\text { e.g. searches memory for English or Arabic } \\
\text { equivalent, Identifies a word or waits for a word } \\
\text { to emerge into "consciousness" }\end{array}$ & 0 & & 0 & & 0 & \\
\hline 2 & Dictionary use & 4 & & 6 & & 5 & \\
\hline III- & Monitoring of ST segments & 23 & $34.33 \%$ & 24 & $29.27 \%$ & 20 & $34.48 \%$ \\
\hline 1 & Repeats linguistic unit & 7 & & 6 & & 3 & \\
\hline 2 & Re-reads ST segment & 8 & & 8 & & 6 & \\
\hline 3 & Generates synonyms & 0 & & 0 & & 1 & \\
\hline 4 & Gives tentative meanings or alternatives & 8 & & 10 & & 10 & \\
\hline 5 & Filters words, skips them & 0 & & 0 & & 0 & \\
\hline & Compares English \& Arabic & 0 & & 0 & & 0 & \\
\hline IV- & Inferencing and Reasoning & 7 & $10.45 \%$ & 11 & $13.41 \%$ & 8 & $13.79 \%$ \\
\hline 1 & World knowledge & & 0 & & 3 & & 1 \\
\hline 2 & Personal experience & & 0 & & 3 & & 0 \\
\hline 3 & Refers to author intent & 0 & & 0 & & 2 & \\
\hline 4 & Constructs explanatory context & 66 & & 5 & & 5 & \\
\hline 5 & Text structure & 1 & & 0 & & 0 & \\
\hline
\end{tabular}




\begin{tabular}{|ll|c|c|c|c|c|c|}
\hline V- & Text contextualization & 7 & $10.45 \%$ & 10 & $12.20 \%$ & 4 & $6.90 \%$ \\
\hline $1 \quad$ Restates prior information & 22 & & 0 & & 0 & \\
\hline $2 \quad$ Uses sentence context & 4 & & 7 & & 3 & \\
\hline $3 \quad$ Uses paragraph context & 11 & & 0 & & 0 & \\
\hline $4 \quad$ Uses larger context & 00 & & 3 & & 1 & \\
\hline VI- Editing or Monitoring of TT segments & 10 & $14.93 \%$ & 15 & $18.29 \%$ & 11 & $18.97 \%$ \\
\hline $1 \quad$ Immediate correction or alteration/selection & & & & & & \\
& of meaning choices & 2 & & 7 & & 6 & \\
\hline $2 \quad$ Congruity assessment & 5 & & 5 & & 3 & \\
\hline $3 \quad$ Punctuation check & 0 & & 0 & & 0 & \\
\hline $4 \quad$ Product quality assessment & 3 & & 3 & & 2 & \\
\hline VII- Extratextual or language use \& task monitoring & 2 & $2.99 \%$ & 2 & $2.444 \%$ & 3 & $5.17 \%$ \\
\hline $1 \quad$ Discovery comments & 0 & & 0 & & 0 & \\
\hline $2 \quad$ Laughs & 0 & & 1 & & 2 & \\
\hline $3 \quad$ Offers personal opinion & 2 & & 1 & & 1 & \\
\hline $4 \quad$ Comments on self as a learner & 0 & & 0 & & 0 & \\
\hline $5 \quad$ Refers to experimenter directly & 0 & & 0 & & 0 & \\
\hline Total & 67 & & 82 & & 58 & \\
\hline
\end{tabular}

As for the first element, it is obvious that the subjects in consideration did use all strategies of both the ST reading comprehension and the TT production. Specifically, the subjects in this study did employ all six strategy types proposed by Gerloff (1986). Also, the strategies they employed cover more or less all strategy types proposed by scholars such as Lörscher (1992, 1996); Krings (1986); Seguinot (1989); among others).

This finding should not surprise us, given the subjects' academic background. These are all graduating students (i.e. enrolled in the last semester of a five-year translator training program at King Saud University, College of Languages and Translation). In particular, these subjects have had extensive translator training in a whole range of fields: Social Sciences, Islamic Studies, Scientific, Technical, Legal and Commercial fields. Moreover, the subjects have had several linguistics courses, namely, Semantics, Text Typology and General Linguistics. We may presume, therefore, that these subjects must have become more or less sensitized to L2 reading comprehension strategies and translation-specific strategies during their translator training courses, albeit in an imbalanced fashion, as will become apparent in the subsequent discussion of these findings.

The second finding is more revealing in the sense that it shows not only the most frequently used strategies but also the most frequently used substrategies of each, respectively. The most frequently used strategies of problem-solving have been the following: Monitoring of ST Segments, Monitoring of TT Segments.

This finding shows that ST reading comprehension and TT production seem to be the foci of these subjects' translation endeavors. It is only natural that most of the subjects' endeavors are centered on the interpretation of ST and the production of TT. More importantly, though, is the variance in employing certain substrategies within these categories, to the neglect of the other substrategies in the same overarching strategy. 
The preceding chart and table (1) show that within the most frequently used strategy of ST monitoring, two or three substrategies were used by the six subjects whereas the others were not. The substrategies most frequently used were: Repetition of linguistic units at level of the word, or morpheme levels, re-reading ST segments, constructing tentative meanings of ST segments in ST language and/or in TT language. Within this strategy (i.e. Monitoring of ST segments) the six subjects did not use the other substrategies: giving synonyms, comparing the two languages, the use of fillers or skipping words.

The strategies used most frequently within the category of Monitoring of TT strategy were: immediate correction before writing and congruity assessment whereby the subject checks to see if the translation makes sense, maybe before writing the product or after. Unused substrategies within this same strategy (i.e. Monitoring of TT Segments) were: punctuation check and product quality assessment.

It is obvious that the subjects' tendency to dwell on the word, morpheme, phrase and to a lesser extent a whole sentence through the repetition of these mini-text segments, re-reading them and giving tentative meanings in SL and TL, reflects the extent of the difficulty they have with bottom-up, language-based text processing strategies.

The findings listed below corroborate the preceding observation concerning

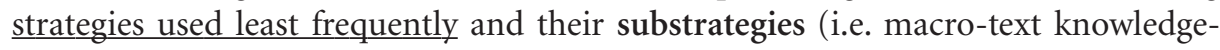
based strategies. These are:

1. Inferencing and Reasoning

- Use of text structure

- Use of world knowledge

- Use of personal experience

2. Storage and Retrieval

- Memory search

3. Text Contextualization

- Use of paragraph context

- Use of larger context

- Reference to author intent

All of the above-named strategies and their substrategies, that either have not been employed or used minimally, constitute the top-down, knowledge-based strategies for text processing. This observation provides further evidence that the subjects are entangled in text processing that is predominantly language-based and "bottom up." Hence, there is an apparent imbalance in their overall strategy use. The balance is tilted towards one set of strategy types at the expense of another equally-important set of strategies. Finally, I must note with some surprise the complete absence of employment of memory search. I posit two reasons for this: the subjects' overwhelming entanglement with the language-based translational problems did not leave enough room for reflection. Secondly, the research design itself may have had an impact. The use of the dialogue think-aloud method of data collection encouraged the paired translators to maximize their collaborative interaction at the expense of private reflection and memory search. 


\section{Conclusion}

Based on the preceding discussion and analysis of data, it is evident that the translator trainees in this study dwelt on language-based, bottom-up processing of the ST. They tended to extract smaller units of the SLT segments and focus their attention on them in order to render the TL text. They chose single words and at best short phrases.

The major problem for these translator trainees is obviously of a local kind, especially lexical transfer; this seems to be a reflection of an inadequate level of competence in SL, especially. Furthermore, and based on the findings that these trainees' translations are dominated by the lexicon and to a certain extent by minimal syntactic units, they do not check the utterances produced in TL with regard to their stylistic and text type adequacy.

These conclusions point to the following: classroom teaching has to incorporate exercises that will confront the translator trainees with the compelling need to utilize the paragraph context, the text structure and their readily acquired previous knowledge. This could be achieved if translator trainers supplement their translation assignments (i.e. SL texts) with a battery of questions that will prompt their trainees to utilize the larger contexts. In other words, translation teachers should transcend their traditional classroom feedback on their students' translations to incorporate the text design, text structure, paragraph structure, and semantic/pragmatic relations that constitute the intricate web of relations underlying whole chunks of utterances, instead of single sentences in isolation.

\section{REFERENCES}

ALI, S.S. (1998): "Symbol, deviation and culture-bound expressions as a source of error in ArabicEnglish poetic translating," Babel 34-4, pp. 211-221.

Al-Khanji, R., El-Shiyab, S. and R. Hussain (2000): "On the Use of Compensatory Strategies in Simultaneous Interpretation,” Meta 45-5, pp. 448-557.

As-SAFI, A.B. (2001): "Lexicalization and Modalization of Prepositions in English-Arabic Translation," International Journal of Arabic-English Studies 2-1/2, pp. 157-169.

Asfoor, M. (2000): "The Translation of Poetry: An Example from Nazik Al-Mala'ika," International Journal of Arabic-English Studies (IJAES) 1-1, pp. 7-39.

Atari, O. F. (1994): “The Place of Communicative Strategies in Translating," Babel 40-2, pp. 65-76. Azız, Y. (1985): "Modes of Address in English-Arabic Translation," Babel 31-3, pp. 144-146.

Barkнo, L.Y. (1987): “Cultural Problems of Arabic-English Political Translation,” Babel 31-3, pp. 146-151.

Börsch, S. (1986): "Introspective Methods in Research on Interlingual and Intercultural Communication," In J. House and S. Kulka (Eds.) Interlingual and Intercultural Communication, pp. 195-209, Gunter Narr Verlag, Tübingen.

Emery, P.G. (1991): “Lexical Incongruence in Arabic-English Translation,” Babel 37-3, pp. 129-137. Emery, P.G. (1989): “Lexical Arabic Texts: Implications for Translation,” Babel 35-1, pp. 1-12.

Farghal, M. (1995): "Lexical and Discoursal Problems in English-Arabic Translation," Meta 401, pp. 54-61.

Farghal, M. and R. Naji (2000): “Translational Miscues in Modern Arabic Verse: A Case Study," IJAES 1-1, pp. 53-72.

Farghal, M. and A. Shunnaq (1992). "Major Problems in Students' Translations of English Legal Texts into Arabic,” Babel 38-4, pp. 201-210. 
Gerloff, P. (1986): “Second Language Learners' Reports on the Interpretive Process: Talk-aloud Protocols of Translation." In J. House and S. Blum-KulKa (eds.) Interlingual and Intercultural Communication, pp. 274-262, Gunter Narr Verlag Tübingen.

Hatim \& Mason (1990): Discourse and the Translator (Chapters one and eleven), Longman.

Krings, H. P. (1986), "Translation Problems and Translation Strategies of Advanced German Learners of French (L2)," J. House and S. Blum-KulKa (eds.) Interlingual and Intercultural Communication, pp. 262-276.

Kussmaul, P. (1995): Training the Translator, (Chapter 1), Amsterdam/Philadelphia, John Benjamins Publishing Company, pp. 5-37.

Lörscher, W. (1996): "Psychological Analysis of Translation Processes," Meta 41-1, pp. 26-32.

- (1992b): "Investigating the Translation Process," Meta 37-3, pp. 426-439.

Menacere, M. (1992). "Arabic Discourse: Overcoming Stylistic Difficulties in Translation," Babel 38-1, pp. 28-37, J. Benjamins Publishing Company, Amsterdam/Philadelphia.

SA'Adeddin, M. A. (2000): "Text Linguistic Criticism of Literary Translations: An Intuitive Heuristic Checklist," IJAES 1-1, Beirut, Libraire du Liban Publishers, pp. 73-103.

Seguinot, C. (Ed.) (1989): “An Experimental Study," in C. Seguinot (ed.) The Translation Process, Toronto, H. G. Publications, New York University.

Shaker, A. (1995): "The Translation of Advertisements: Registeral and Schematic Constraints," Meta 40-1, pp. 62-72.

Shunnaq, A. T. (1999): "Repetition and Redundancy," In M. Farghal and A. T. Sunnaq. Translation with Reference to English and Arabic: A Practical Guide, Irbid-Jordan, DAR Al-Hilal for Translation, pp. 136-140.

TirkKonen-Condit, S. (ed.) (1991): Empirical Research in Translation and Intercultural Studies, Tübingen. 


\section{APPENDIX 1}

Translate the first three paragraphs of the following passage into Arabic:

Romania is fertile ground for US firms

\section{Kate Connolly in Giorgiu}

Petre MINCA stoops to pick up a handful of soil from his modestly-sized farm in the village of Daia, in southern Romania. $\mathrm{He}$ holds it at shoulder height and lets it run through his fingers.

"This is so-called pamant negru or "black soil' and is considered to be some of the best in the world," he says. It is rich in organic matter, low in salinity, extremely regenerative - and under-exploited. It earned Romania the title of the "breadbasket of Europe" between the wars. Wheat, corn and sunflowers are the main crops.

The farmer remembers his father's accounts of how the Germans transported trainloads of it home to enrich their agricultural output during the second world war. But despite owning 13 hectares Mr Minca has - since the land was returned to him in 1990, after 50 years of collectivism - been unable to make it pay. He blames a lack of government subsides, bad management and cheap imports. All over Romania, the story is the same.

He and his family work their holding by hand, occasionally borrowing a horse-drawn plough from a neighbour in exchange for part of crop. His wife bakes bread in an oven in the backyard. From what little he sells locally, Mr Minca supports his wife, their four sons and his mother on an income of $\$ 70$ a month.

But for the 51-year-old Mr Minca and the other farmers of Daia, in the country of Giorgiu close to the Bulgarian border, times are about to change. Under a deal with the Romanian government, American agribusiness is about to arrive.
A consortium of some of the biggest names in the sector - Monsanto, Cynamid, Du Pont and FMC will be moving in seed, fertilizers and chemicals, while modern equipment is shipped in by John Deere, Valmont and Lindsay.

The farmers are to get combine harvesters, tractors and other modern tools to replace the horse-drawn ploughs. In exchange they will be required to rent out most of their land to the consortium, keeping a small amount for personal use.

From the land they rent out the farmers believe they will receive the proceeds of onethird of the yield - after costs are deduced while the consortium will keep tow-third. For the farmers, a key inducement is that, regardless of the harvest they say they have been guaranteed, a minimum income level the proceeds of 1 tonne per hectare. In Five years' time, if they choose to go it alone, the equipment will be theirs.

In fact, it appears that the best they may get is 15-25 per cent of the yield before costs are deducted. Even this level, however, is more than the farmers could reliably expect under their current system.

\section{APPENDIX 2}

Samples of the subjects' think-aloud tape-scripts

\section{Sample one:}

Adel: (reading slowly).. Ro... Roma...nia.. (pause) firms. What's "firms"?

Fahed: (Reading slowly simultaneously with Adel) Oh! I've found it here in the dictionary .... It means company.

Adel: (Reading and rereading) Petre Minika ... (pause) ... Petre ... stoops ... (pause) to pick up ... (re-reads) Peter Mainka ... Minka ... stoops to... to pick up ... stoops to pick up... "stoops" ... "What's this?" 


\section{Sample two:}

Bader: ...transported trainloads??

Mazin: 'almagsu:d hinð naglau: 'an tari:g the inteded here they transported via road 'il-kita:r kamiyyat kabi:ra minil-maHasi:l the train quantities large from the crops... what's meant here is that they transported by train large quantities of the crops...

Bader: "enrich" eiS ma’anæhə

What's meaning its

Enrich ... what's its meaning?

Mazin: "to enrich” ... ydzi:d 'aw dzæy min rich 'illi hi:l ghin exceeds or coming from rich which it is the wealth to enrich means exceeds or it is taken from rich which is wealth ...

Mazin: (goes on to ask) agricultural ... eiS ma'anæhд?

What is meaning its?

What's its meaning?

Bader: 'atagid zira:'iyya, zira:'iyya..

I believe agricultural, agricultural..

I think it means agricultural ... (a long pause)

Mazin: ... (reading) ... but despite owing 13 hectares Mr. Minca.. mi:n kæn yigsid bi Mr Minca? Petre 'aw 'abu:h? who(m) did mean he by Mr Minca Petre or father his whom did he mean by saying Mr. Minca, Peter or his father?

Bader: Wal-la:h mæ 'adri ... ba'adhд nigra' Swai wa na'arif by Allah not I know ... after it we read a little and know we mi:n 'ktub Mr. Minca wa khalas whom write Minca and that's enough I honestly (by Allahs' name) don't know ... let's read more and we'll know whom he meant. Just write Mr. Minca and that will be it.

\section{APPENDIX 3}

Examples of the use of Problem Identification, the use of dictionary and Monitoring of ST segments by repeating and re-reading linguistic unit.

S1*: (Reading slowly). Ro... Roman... (pause) ... firms. What's "firms"?

S2: Oh! I've found it here in the dictionary...It means /Sharika/ "company." S1: ...Petre... Minika... (pause) Petre... stoops (pause) to pick up... (Re-reads) Peter Maink... Minka stoops to ... stoops to pick up... stoops... what's this?

S2: (Reading silently) Let's look it up in the dictionary.

\section{Monitoring of ST Segments}

Subject generates alternative meanings or states tentative or general meaning

S1: (Reading slowly)

Romania is fertile ground for US firms "firm".../Sharika/ company?

S2: Yeah..., Yeah... /'ard khasba li-Sh Sharikat 'al -'amrikiyya/ Land fertile for the companies the American fertile land for American companies...

S1: How? How do you mean?

S2: It means new markets... new markets... yeah... fresh... l'aswaq dzadi:d d/ markets new new markets 


\section{Inferencing and Reasoning}

A Subject uses world knowledge or personal experience to question the text, hypothesize a meaning or to state or verify a hypothesized meaning:

S1: (Reading the ST segment): ...He holds it at shoulder height... "at his shoulder..." can’t it mean "ala 'atiqihi" upon his responsibility?

S2: No! No! "height" "irtifa" how can you say at his responsibility's heights? We can only say: "'ala 'irtifae'i katifih"

Upon height his shoulder

"at his shoulder height"...

\section{Monitoring of TT Segments}

i) Immediate correction or alteration/selection of meaning choices before writing.

ii) Congruity assessment: subject checks to see if translation makes sense; maybe before writing the product or after

S1: ... so how do we translate this...? Then? Does it mean that Romania...

/ hal ta'ni: 'ard khasba?/

does it mean land fertile?

/Lil-sharikat 'al-'amri:kiya?"/

For the companies the-American

does it mean fertile land for American companies"...

S2: Yeah, it fits in or we can say...

/ 'aswaq dzdi:d $\partial$ / new markets... markets new

/'aswaq muHabbaba"/

markets favoured...

favoured markets...

Another example of congruity assessment and the use of sentence context to infer meaning:

S1: /Kamiyya mutawa:dia' 'aHsan li'annu

amount modest better because

turab qasdu /

soil he means

... a modest amount is better because "soil" he means...

S2: No! No! modestly-sized farm" means

mazra’a Hajimha saghi:r

farm its size small

/aw Hajim mutawaidi' ... ya'ni mazra’a saghi:ra/

it means Farm small

It means: a farm of a small size or a modest size... that is ... a small farm.

The word "farm" came after "modestly-sized" so it refers to "Hajim" "size" not "kamiyya" "quantity" or "amount."

* $\mathrm{S} 1=$ Subject one

S2 $=$ Subject two 